\title{
IN MEMORIAM :
}

\section{Prof. dr. S. F. H. J. Berkelbach v.d. Sprenkel deur}

Dr. P. J. Theo. KoEKemoer

In die begin van hierdie jaar, in die vroeë oggendure van 18 Januarie, is in Utrecht, Nederland, oorlede 'n bekende teoloog, Berkelbach v.d. Sprenkel. Op die Senaatsvergadering van die Utrechtse Universiteit het prof. van Ruler soos volg verklaar: „Almal sal daarvan kan getuig dat Berkelbach se leerlinge 'n vormende, stralende en besielende invloed van hom ondergaan het; van hom nie alleen as mens nie maar as beoefenaar van die praktiese Teologie. Ek sê: al sy leerlinge”. Van Ruler bereken dat sy studentetal oor die sewentien jare van sy professoraat meer as duisend beloop. "Op AL sy leerlinge ..." is seker nie te vergesog nie!

Dit sal gepas wees om ook in die H.T.S. iets oor hierdie groot man, groot van gees, te sê. Sy grootheid sal na sy dood eers reg waardeer kan word, juis omdat hy enige mensverheerliking so skerp veroordeel het. God alleen is groot en goed. Die mens is dit nie. Soli Deo Gloria! Met sy aftrede as professor was daar geen afskeidslesing of seremonie van watter aard ookal nie. Hy het dit onverbiddelik so en nie anders nie, verkies. By 'n afskeid kom die grootheid van die mens onmiskenbaar op die voorgrond. Hy wou geen „Feesbundel" en geen huldiging hê nie. Dit was deur homself so gereël dat nie een van sy medeprofessore, kollegas, op sy begrafnis sal optree nie. Waarom so? Alleen om een rede: Dit gaan nie om die kerklike hoogleraar Berkelbach nie maar om die Heer van die Kerk, die Heer wat hy sy lewe lank gedien het. Wie Berkelbach geken het, sy lesings gevolg het, die privatissima in sy studeerkamer geniet het, met hom kon gaan wandel langs die bekende Utrechtse straat, die Maliebaan, sal weet dat dit alles beslis geen valse nederigheid was nie. Hy het 'n saak gedien, die saak wat groter as hyself is, die saak van die Heer van die Kerk. Hy, die Heer, was meer; Berkelbach was minder.

Berkelbach v.d. Sprenkel is op 10 April 1882 gebore in die pastorie van Nederhemert. Dit was sy eie keuse om die voetstappe van sy vader te volg. Aan die Universiteit van Utrecht het hy sy teologiese studie voltooi. Ook was hy as student ge- 
interesseerd in die Wysbegeerte. Die filosoof Bolland het hom as leermeester hierin voorgegaan. Sy voorliefde vir die Ou Testament het hom gebring aan die voete van Valeton. Sy liefde vir die vak Dogmatiek was reeds in sy studentejare baie duidelik: die Outestamentikus Valeton het hiermee te doen gekry toe hy op aandrang van studente, met Berkelbach op die voorpunt, 'n reeks lesings gegee het oor die Apostolicum. Dit was egter die Leidse professor (gereeld het hy en sy jeugvriend M. J. A. de Vreijer na Leiden gegaan) P. D. Chantepie de la Saussaye wat miskien die grootste bydrae gelewer het tot die vorming van die teologiese denke van die jong predikant, Berkelbach. Hier het hy die Etiese Teologie sistematies kon deurdink. Hierdie man was werklik student in die ware sin van die woord. Voordat hy hom beroepbaar stel, wou hy nog verder gaan besin. Wie hom wend tot die ,waagstuk" van die prediking, moet weet wat hy doen. In Berlyn studeer hy verder en word leerling van die wêreldbekende dogmenhistorikus, Adolf von Harnack. Elke student van Berkelbach is daarvan terdeë bewus: die dogmatikus moet die geskiedenis van die dogma ken.

In 1907 word hy predikant te Wijk aan Zee, in 1915 te Purmerend, in 1919 te Haarlem, in 1925 te Rotterdam en in 1933 te Amsterdam. Vir agt-en-twintig jaar staan Berkelbach dus voltyds as Verbi Divini Minister. Hierdie geweldige ervaring van die pastoraat, teen die agtergrond van sy deeglike studie, het seker grootliks daartoe bygedra, dat ons, sy studente, dit altyd kon aanvoel: die antwoorde op ons vrae is geen bloot teoretiese antwoorde nie maar antwoorde gegrond in die praktyk van die Kerk.

Berkelbach was 'n begenadigde prediker. Hy het die gawe gehad om met 'n aangrypende voordrag (kalm en rustig), met 'n welluidende stem sy gehoor se aandag af te dwing. So het hy dit telkens herhaal aan sy studente: ,hoofsaak is dat daar 'n teks moet wees". Aan hierdie teks is jy gebonde. Aan hierdie teks is alles onderhorig. Die prediker is assistent. Maar . . naas die teks was daar mense, 'n gemeente, uitgeroepenes van die Heer. Hierdie mense moet begryp word. Almal is beelddraers van God: adelstand en volkstand. Bybels-reformatories is hy begaan oor die mens, ver weg van elke sweem van humanisme.

Sy werk op kerklike gebied het gestrek ver anderkant die grense van sy gemeentes. Hy was bekend as 'n voorsitter wat meningsverskille op meesterlike wyse kon hanteer. O.a. was hy voorsitter van die kommissie wat die nuwe Kerk-orde van die Nederlands Hervormde Kerk moes opstel. Dit was geen geringe 
taak nie. Van 1947 tot 1954 was hy voorsitter van die Ekumeniese Raad van Kerke in Nederland. In hierdie jare was die Ekumene nog grootliks op Bybelse gronde bewoë oor die verdeeldheid van die Kerk. Berkelbach sou elke vorm van humanistiese filosofie op 'n afstand kon ruik. Hy het die verskil geken tussen die Bergrede en die V.V.O.-rede. Nadat hy as professor afgetree het, doseer hy nog vir vyf jaar tot 1970 Ekumenika.

In 1935 is Berkelbach deur die Algemene Sinode van die Nederlandse Hervormde Kerk benoem tot kerklike professor, as opvolger van prof. $M$. van Rhyn. Nadat van Rhyn afgetree het, is daar in Holland ' $n$ sterk poging aangewend om die bekende dogmatikus, Karl Barth, in Utrecht te kry. Dit het egter misluk. Nietemin het Barth 'n reeks lesings in Utrecht gegee, ook oor die Apostolicum. Hierdie lg. lesings is in Nederlands vertaal en met kommentaar voorsien deur prof. dr. K. H. Miskotte. Berkelbach kry van sy Kerk die leer-opdrag in Dogmatiek, Praktiese Teologie en Kerkreg. Van nou af was dit sy lewenstaak.

Sonder om aanspraak op volledigheid te maak, noem ons hier teologiese publikasies van prof. Berkelbach:

1. Sy proefskrif (met lof): „Vrees en Religie, Een Psychologische Onderzoek toegepast op Nieuw Test. Gegevens". 1 Julie 1920. Promotor: Prof. H. Visscher.

2. Sy Inaugurele rede: „Over de Verkondiging”. 6 Mei 1935.

3. In 1958 verskyn die tweede uitgawe van sy „Evangelie naar Marcus".

4. In 1964 verskyn sy „Evangelie naar Lucas”.

5. In die reeks „,De Prediking van het N: Testament”, skryf hy in 1941 sy kommentaar op die brief aan die Efesiërs.

6. „Huwelijkscathechisatie”, Nijkerk 1946.

7. In die Postilles van 1957 tot 1964 behandel hy in homiletiese sketse die Heidelbergse Kategismus in sy geheel.

8. Die laaste deel van die Kategismus behandel hy in „Het Gebed", Nijkerk 1948.

9. „Cathechetiek”, Nijkerk 1956.

10. „Geloof, Symbool, Middelaar naar den Brief aan de Hebreën”, Utrecht 1917.

11. „Het Offer”, Rotterdam. 
12. „Huisbezoek”, Amsterdam 1946.

13. „De Prediking in den Adventstijd” en „De Prediking als Bijbellezing”, in „Handboek voor de Prediking”, Amsterdam 1948. Inleiding in die bundel „Het $\mathrm{N}$. Test. Kerkbegrip en onze Kerken", Amsterdam 1951.

14. „Christus en zijn Kerk”, in „Drie Oecumenische Studies”, Amsterdam 1953.

15. „De Mens en de Prediking”, in „Waarheid, Wijsheid en Leven", Kampen 1956.

16. „De Prediking, de Prediker en de Kerkganger”, s'Gravenhage 1957.

Ons eer die nagedagtenis van S. F. H. J. Berkelbach v.d. Sprenkel. 